Edisi Januari - Juni 2020 Vol 19 No 1

\section{JURNAL ILMU PEMERINTAHAN}

\section{nakhoda}

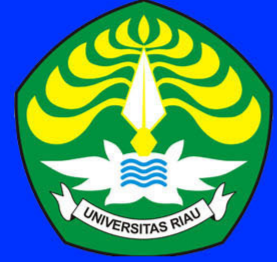

Innovation Hub: Media Kolaborasi Menuju Pemerintahan Daerah Inovatif Herie Saksono

Institusional Building dalam Mengatasi Persoalan Pertambangan Emas Tanpa Izin Di Kabupaten Kuantan Singingi Provinsi Riau

Khotami

Gerakan Masyarakat Tertib Administrasi Kependudukan Melalui Inovasi Pelayanan Lukadesi (Keluarga Berduka Desa Siaga)

Di Kabupaten Sleman D.I Yogyakarta

Hendy Setiawan, Fariza Ikhsanditya

Provinsi 'Istimewa Melayu Riau Kepulauan'

Muchid Albintani, Auradian Marta

Kaderisasi dan Penetapan Calon Legislatif pada Partai Politik (Studi DPD Partai Nasional Demokrat Seram Bagian Barat 2019)

Fandi Ahmad Sintani, Wahab Tuanaya, Marno Wance

Factors of Affect Deliberation of Maguwoharjo

Village Development Planing Sub-District Depok Regency Sleman Yogyakarta Muhammad Rafi, Ulung Pribadi, Fajar Rahmanto

Survey Kepuasan Masyarakat (SKM) pada Badan PendapatanDaerah Kabupaten Bintan

Suherry, Billy Jenawi, Rendra Setyadiharja,

Zamzami A Karim, Firman Setyawan, Rany Angraini

Peran Dewan Perwakilan Daerah (DPD) dalam

Pembentukan Daerah Otonomi Baru (DOB) Di wilayah Provinsi Maluku Utara

Abdul Halil Ibrahim, Bakri La Suhu, Rifjal Tifandy, Marno Wance

MEDIA INFORMASI DAN KOMUNIKASI ILMIAH CIVITAS AKADEMIKA JURUSAN ILMU PEMERINTAHAN

FAKULTAS ILMU SOSIAL DAN ILMU POLITIK

UNIVERSITAS RIAU
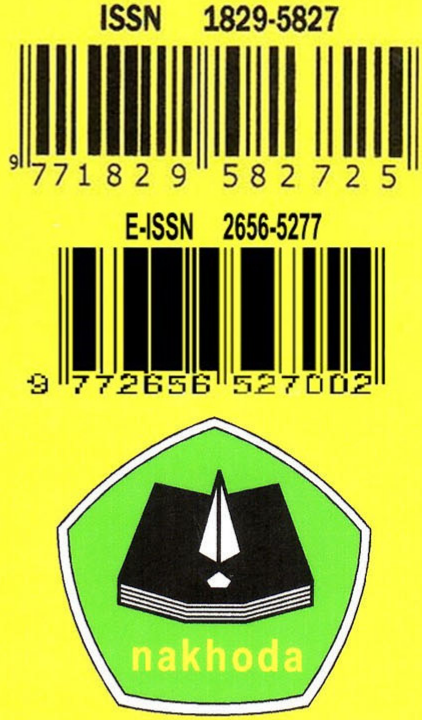

DITERBITKAN OLEH :

LABORATORIUM ILMU PEMERINTAHAN
SEKRETARIAT :

KAMPUS BINA WIDYA SIMPANG BARU

PANAM KM. 12,5 PEKANBARU

(28293) Telp/Fax. (0761)63277 
NAKHODA:

JURNAL

ILMU PEMERINTAHAN
NAKHODA: JURNAL ILMU PEMERINTAHAN

Edisi Januari - Juni 2020 Volume: 19 Nomor: 1

ISSN : 1829-5827 | E-ISSN : 2656-5277

DOI : https://doi.org/10.35967/jipn

https://nakhoda.ejournal.unri.ac.id/index.php/JIPN

INNOVATION HUB: MEDIA KOLABORASI MENUJU PEMERINTAHAN DAERAH INOVATIF

Herie Saksono

Badan Penelitian dan Pengembangan (BPP) Kementerian Dalam Negeri, Jakarta, Indonesia

$1-16$

INSTITUTION BUILDING DALAM MENGATASI PERSOALAN PERTAMBANGAN EMAS

TANPA IZIN DI KABUPATEN KUANTAN SINGINGI PROVINSI RIAU

Khotami

Program Studi Ilmu Pemerintahan, Fakultas IImu Sosial dan IImu Politik Universitas Islam Riau. 17 - 37

Pekanbaru-Indonesia

GERAKAN MASYARAKAT TERTIB ADMINISTRASI KEPENDUDUKAN MELALUI INOVASI

PELAYANAN LUKADESI (KELUARGA BERDUKA DESA SIAGA) DI KABUPATEN SLEMAN

D.I. YOGYAKARTA

Hendy Setiawan ${ }^{1}$, Fariza Ikhsanditya ${ }^{2}$

1,2 Departemen IImu Pemerintahan, Universitas Muhammadiyah Yogyakarta, Yogyakarta,

Indonesia

PROVINSI “ISTIMEWA MELAYU KEPULAUAN RIAU” (GAGASAN PERMULAAN)

Muchid Albintani', Auradian Marta ${ }^{2}$

1,2 Jurusan IImu Pemerintahan, Fakultas IImu Sosial dan IImu Politik, Universitas Riau

KADERISASI DAN PENETAPAN CALON LEGISLATIF PADA PARTAI POLITIK (Studi DPD

Partai Nasional Demokrat Seram Bagian Barat 2019

Fandi Ahmad Sintani ${ }^{1}$, Wahab Tuanaya ${ }^{2}$, Marno Wance ${ }^{3}$

1,2,3 Jurusan IImu Pemerintahan, Universitas Pattimura, Indonesia

$75-90$

FACTORS THAT AFFECT DELIBERATION OF MAGUWOHARJO VILLAGE DEVELOPMENT

PLANNING SUB-DISTRICT DEPOK REGENCY SLEMAN YOGYAKARTA

Muhammad Rafi ${ }^{1}$, Ulung Pribadi2, Fajar Rahmanto ${ }^{3}$

1,2,3 Department of Government Affairs and Administration, Universitas Muhammadiyah

Yogyakarta, Indonesia

SURVEY KEPUASAN MASYARAKAT (SKM) PADA BADAN PENDAPATAN DAERAH

KABUPATEN BINTAN

Suherry ${ }^{1}$, Billy Jenawi², Rendra Setyadihardja ${ }^{3}$, Zamzami A. Karim4,

Firman Setiawan ${ }^{5}$, Rany Angraini ${ }^{6}$

$102-112$

1,2,3,4 STISIPOL Raja Haji, Tanjungpinang, Indonesia

5,6 Bapelitbang, Bintan, Indonesia

PERAN DEWAN PERWAKILAN DAERAH (DPD) DALAM PEMBENTUKAN DAERAH

OTONOMI BARU (DOB) DI WILAYAH PROVINSI MALUKU UTARA

Abdulhalil Hi. Ibrahim ${ }^{1}$, Bakri La Suhu2, Rifjal Tifandy 3 Marno Wance 4

1,2,3 IImu Pemerintahan Universitas Muhammadiyah Maluku Utara, Kota Ternate, Indonesia

$113-127$

${ }^{4}$ IImu Pemerintahan, Universitas Pattimura, Kota Ambon, Indonesia 


\title{
KADERISASI DAN PENETAPAN CALON LEGISLATIF PADA PARTAI POLITIK (Studi DPD Partai Nasional Demokrat Seram Bagian Barat 2019
}

\author{
Fandi Ahmad Sintani ${ }^{1}$, Wahab Tuanaya ${ }^{2}$, Marno Wance ${ }^{3}$ \\ ${ }^{1,2,3}$ Jurusan Ilmu Pemerintahan, Universitas Pattimura, Indonesia \\ E-mail:ipmummu@gamil.com
}

\begin{abstract}
ABSTRAK
Partai politik memiliki sistem perkaderan yang berbeda untuk melakukan tahapan seleksi kader yang selektif, transparan serta demokratis. Tujuan dari rekrutmen kader dengan maksud untuk dapat memperoleh kader yang ideal dalam memperjuangan kepentingan masyarakat dan memahami visi partai. Partai politik akan terus melakukan kaderisasi secara terus menerus untuk mendapat pemimpin masa depan bangsa dan Negara. Metode yang digunakan pada penelitian yaitu kualitatif untuk dengan melakukan wawancara mendalam dengan informan pilihan di partai Nasdem Seram Bagian Barat. Berdasarkan hasil penilitian pada DPD II partai Nasional Demokrat (Nasdem) Seram Bagian Barat dalam melakukan proses kaderisasi dan penetapan calon legislatif Partai Belum sesuai dengan cita-cita besar Demokrasi. Kaderisasi yang dilakukan partai Nasional Demokrat Kabupaten Seram Bagian Barat ini hanya sebagai persyaratan partai menjelang Pemilu dilaksanakan. Proses seleksi calon legislatif sebaiknya pada partai politik secara terbuka dengan ketentuan mengikuti proses yang ditentukan oleh internal partai yang meliputi syarat yang ditentukan dan prosedur yang diketahui oleh masyarakat umum. Keterbukaan dalam proses seleksi menjadi uji publik calon anggota legislatif untuk masyarakat dapat menilai kemapuan dari kadidat calon yang di usulkan oleh partai politik.
\end{abstract}

\section{Kata Kunci : Partai Politik, Kaderisasi, Penetapan Calon Legislatif, Partai Nasional Demokrat}

\section{PENDAHULUAN}

Diawali dengan Pemilu Legislatif yang berlangsung tanggal 9 April 2009 sampai pada pemilu 17 April 2019 ternyata masih meninggalkan berbagai persepsi didalam masyarakat. Pesta demokrasi yang merupakan proses demokrasi pemerintahan di Indonesia ini, ternyata banyak meninggalkan tanda tanya besar.

Pemilihan umum pada tanggal 9 April 2019 merupakan rangkain pemilu serentak yang akan dilaksanakan sebagai model pelaksanaan pemilu di Indonesia. Demokrasi lima tahunan yang dilaksanakan untuk memilih kandidat pemimpin bangsa untuk mengemban amanah di lembaga legislatif. Demokrasi langsung merupakan pesta pemilihan yang dilaksanakan untuk memilih anggota legislatif untuk masa jabatan lima tahun kedepan.

Pemilihan umum yang dilaksanakan secara langsung selama ini menyisahkan konflik kepentingan elit partai politik untuk memenangkan suara rakyat dengan 


\author{
NAKHODA: JURNAL ILMU PEMERINTAHAN \\ Edisi Januari - Juni Tahun 2020 Volume: 19 Nomor: 1 \\ ISSN : 1829-5827 | E-ISSN : 2656-5277 \\ DOI : https://doi.org/10.35967/jipn \\ https://nakhoda.ejournal.unri.ac.id/index.php/JIPN
}

cara-cara yang bertentangan dengan norma hukum pemilihan umum. Persoalan daftar pemilih tetap (DPT) masih menjadi pekerjaan para penyelenggara pemilihan umum dan pemerintahan untuk menyelesaikan daftar pemilih ganda yang sering menjadi pemicu konflik politik. Persoalan pemilu misalnya surat suara yang tertukar, suara kandidat yang hilang saat perhitungan dan kesalahan cetak surat suara. Proses pemilihan umum menjadi instrumen yang penting untuk meningkatkan kualitas demokrasi menuju transisi kepemimpinan yang melibatkan aktor partai politik. Pola rekrutmen yang berbeda-beda antara satu partai dengan partai yang lain menjadi ukuran dalam proses rekrutmen kader yang dilakukan oleh pemimpin partai. Pola rekrutmen kader yang berjalan secara terus menerus dengan kaderisasi berjenjang yang dilakukan setiap tahun sangat menentukan kualitas anggota legislatif. Tata kelola partai secara kolektif organisasi dapat membentuk karakter kader yang bijaksana dalam menjalankan norma-norma ideologis yang menjadi prinsip dasar partai politik dalam menjalankan praktek kekuasaan yang di terapkan dalam kehidupan politik.

Pola rekrutmen partai berbeda-beda dalam melakukan kaderisasi serta rekrutmen kader baru yang ditentukan oleh mekanisme partai dan sistem politik yang dianut oleh Negara. Pembahasan menarik tentang peran dan fungsi pemerintah dalam memposisikan dirinya secara proporsional dan juga kemampuan partai politik untuk mengatur dirinya sendiri dan kemampuan untuk mempertahankan dominasi perannya dari intervensi kekuasaan. Kematangan partai politik tergantung dari tingkat kedewasaan partai dalam melakukan seleksi terhadap calon pemimpin lokal maupun nasional secara selektif dengan metode dan teknis yang mampu menjunjung visi demokrasi yang jujur dan bermartabat. Pemimpin yang menahkoda partai sudah tentu memiliki visi pengembangan serta langkah yang strategis untuk memilih metode rekrutmen yang transparan dan akuntabilitas sehingga berdampak pada kualitas kandidat yan dipilih oleh partai politik.

Idealnya sistem seleksi partai harus mempertimbangkan calon anggota legislatif yang bergabung menjadi anggota kader dan kandidat mempertimbangkan keaktifan pada partai politik selama beberapa tahun. Faktor keaktifan dalam partai politik dengan tujuan sehingga anggota partai dapat diberikan pendidikan politik melalui internal partai politik dengan metode pelatihan, workshop dan seminar secara rutin. Pengetahuan kader partai politik sangat menentukan kualitas kandidat dalam mengelola politik secara bijak dengan pendekatan normatif yang diatur dalam perundang-undangan.

Dengan demikian proses seleksi kandidat untuk menjadi calon anggota legislatif pada partai politik sudah melalui jenjang seleksi yang telah berlangsung beberapa tahun sebelum di tetapkan menjadi kandidat ataupun kader partai. Seleksi partai politik dengan pendekatan platform ideologi, kandidat memiliki visi dan misi yang sesuai dengan partai politik untuk mencapai cita-cita sesuai dengan kepercayaan dalam membangun bangsa dan Negara. Proses seleksi yang akuntabilitas dapat merekrut kader berdasarkan kriteria yang memiliki 


\author{
NAKHODA: JURNAL ILMU PEMERINTAHAN \\ Edisi Januari - Juni Tahun 2020 Volume: 19 Nomor: 1 \\ ISSN : 1829-5827 | E-ISSN : 2656-5277 \\ DOI : https://doi.org/10.35967/jipn \\ https://nakhoda.ejournal.unri.ac.id/index.php/JIPN
}

kebebasan, jiwa kader yang objektif tanpa memandang latar belakang, kandidat memiliki kemampuan, keahlian, dan kandidat yang memiliki nilai kejujuran sehingga dapat terhindar dari korupsi, gratifikasi, kolusi, serta nepotisme.

Pendekatan Partai Nasdem dalam merekrut anggota legislatif memiliki 4 (empat) kriteria yaitu:

1) Kader partai memiliki kompetensi yang memadai untuk dapat menjalankan tugas-tugas sebagai anggota legislatif.

2) Memiliki pengabdian selama menjadi kader partai serta memiliki rekam jejak yang baik selama aktif di Partai Nasdem.

3) Memiliki prestasi, dedikasi, disiplin, loyalitas dan tidak tercela (PD2LT).

4) Memenuhi ketentuan yang disyaratkan oleh undang-undang.

Partai politik tanpa kaderisasi tidak berarti apa-apa, keberlangsungan partai politik membutuhkan kader yang memiliki kualitas dan kemampuan. Proses seleksi sudah tentu akan dilakukan tetapi untuk memproduk hasil kader yang baik maka dibutuhkan proses kaderisasi yang sistematis, berjenjang dan terus menerus dilakukan. Kaderisasi yang dilakukan membutuhkan kemitmen semua pihak untuk saling membantu dan mendukung proses rekrutmen kader yang baru bergabung. Keberhasilan perkaderan juga sangat ditentukan oleh model training yang dilakukan, misalnya penyajian materi yang diberikan pada saat pelatihan dengan tujuan menghasilkan kader yang berkualitas. Kualitas kader yang dimiliki oleh partai politik menjadi laboratorium bagi partai untuk menyediakan pemimpin nasional dan daerah untuk mendorong visi pembangunan yang berkualitas.

Transisi kepemimpinan dari generasi tua ke generasi muda sangat ditentukan penyiapan perkaderan yang sistematis, benjenjang untuk penyiapan kader yang berkuliatas dan memiliki cita-cita pembangunan. Kebebasan demokrasi memberikan partai politik untuk dapat mengembangkan tugas yang tidak ringan, Penyaluran aspirasi melalui daerah pemilihan menjadi agenda DPRD untuk dapat mengubah kebijakan publik yang berkepentingan kepada masyarakat. Partai politik menjadi pilar utama dalam memberikan pendidikan kepada kader baru. Tujuan dari pendidikan politik untuk dapat memastikan keberlangsungan organisasi di masyarakat, menciptakan kesejahteraan sosial bagi seluruh rakyat Indonesia. Keberhasilan kaderisasi partai jika mampu memproduk kader yang memiliki loyalitas, kemampuan untuk memecahkan persoalan bangsa dan Negara. Kemampuan untuk memahami kebutuhan masyarakat yang diwakili dengan menyaring aspirasi masyarakat dan diperjuangankan pada level kebijakan publik.

\section{Konsep Kaderisasi}

Kaderisasi politik adalah model pengisian jabatan organisasi pada lembagalembaga politik seperti partai politik, administrasi birokrasi dan elit yang menjalankan kekuasaan Negara. Pengisian lembaga-lembaga politik melalui jenjang perkaderan yang sistematis melalui mekanisme internal maupun eksternal dalam memperoleh pemimpin masa depan yang mampu menganalisis permasalahan pada sistem politik. (Suharno, 2004: 117). 


\author{
NAKHODA: JURNAL ILMU PEMERINTAHAN \\ Edisi Januari - Juni Tahun 2020 Volume: 19 Nomor: 1 \\ ISSN : 1829-5827 | E-ISSN : 2656-5277 \\ DOI : https://doi.org/10.35967/jipn \\ https://nakhoda.ejournal.unri.ac.id/index.php/JIPN
}

Kaderisasi politik merupakan elemen mendasar dalam organisasi politik untuk dapat memberikan satu sosialisasi politik. Sistem sosialisasi politik adalah mekanisme untuk dapat memperkenalkan sistem politik kepada seseorang, kelempok tertentu serta bagaimana kader parrati tersebut menentukan tanggapan serta reaksi-reaksinya terhadap gejala-gejala politik (Hafied Cangara, 2008: 25). Kaderisasi partai politik menjadi bagian yang terpenting dalam manajemen tata kelola kepartaian yang baik serta ciri keberlangsungan organisasi. Sedangkan menurut Miriam Budiardjo, Kepartaian yang memiliki kader-kader yang pengetahuan baik serta berkualitas dapat mampu memberikan kesempatan yang besar kepada kader partai untuk dapat mengembangkan pengetahuan dan dapat memberikan inovasi untuk pengembangan kemajuan partai. Rekrutmen politik dapat menentukan kontinuitas dan kelestarian partai untuk dapat bersaing dengan kekuatan kontestasi politik yang semakin ketat. Seleksi kepemimpinan untuk menjaring dan melatih calon-calon pemimpin dengan berbagai cara yang dapat dilakukan dalam Kaderisasi politik yaitu melalui kontak pribadi, persuasi dengan tokoh di masyarakat, ataupun metode lain yang dapat meningkatkan elektabilitas partai pada arena pemilu (Miriam Budiardjo, 2008: 408).

Berdasarkan hasil temuan penelitian menunjukan bahwa tingkat partipasi politik pemilih pemula dalam menentukan pilihan politik pada pemilihan kepala daerah Maluku Utara yaitu sebagai berikut pemilih pemula sudah cukup rasional dalam memutuskan pilihan politknya, karena yang menjadi indikator penilaian adalah ketokohan kandidat atau figur yang dimiliki oleh kandidat tertentu, serta produk isu-isu politik yang coba dijual berupa program-program kerja kandidat tertentu. di samping itu juga ternyata pemilih pemula masih menggunakan pendekatan emosional dengan kandidat dalam menyalurkan hak suara pada pemilihan (Wance, 2019)

Seleksi kepemimpinan melalui proses kaderisasi memiliki peran yang sangat penting untuk dapat memiliki kader partai yang memiliki visi dan misi untuk kemajuan organisasi partai. Adapu nilainilai kaderisasi adalah sebagai berikut:

a) Nilai-nilai organisasi yang baik adalah proses untuk memindahkan nilai dari individu ke individu yang lain. Bentuk dari nilai-nilai dapat berupa yang tertulis atau yang tercantum dalam aturan organisasi ( konsensi, AD/ART, aturan yang lain) maupun nilai yang tidak tertulis pada masyarakat sejak masa lalu dan masih dipertahankan sehingga saat ini.

b) Keberlangsungan organisasi yang baik adalah tata kelola organisasi yang mengimplementasikan proses kaderisasi untuk keberlangsungan kader kedepan. Proses perkaderan menentukan kualitas sumber daya manusia (SDM) pada organisasi jika SDM memiliki kualitas kepemimpinan dapat memastikan keberlangsungan organisasi.

c) Kualitas sarana belajar bagi anggota organisasi yang baik dan memadai sangat menunjang kematang institusional organisasi dalam mendidik kader masa depan. Pendidikan yang dilakukan oleh 


\author{
NAKHODA: JURNAL ILMU PEMERINTAHAN \\ Edisi Januari - Juni Tahun 2020 Volume: 19 Nomor: 1 \\ ISSN : 1829-5827 | E-ISSN : 2656-5277 \\ DOI : https://doi.org/10.35967/jipn \\ https://nakhoda.ejournal.unri.ac.id/index.php/JIPN
}

organisasi sebagai sarana mendewasakan manusia melalui pengajaran dan pelatihan.

\section{Pengertian Partai Politik}

Partai politik merupakan salah satu sarana yang menghubungkan antara pemerintah dengan rakyat. Secara umum dapat dikatakan bahwa partai politik adalah suatu kelompok yang teroganisir, yang anggota-anggotanya mempunyai orientasi, nilai-nilai, dan cita-cita yang sama. Tujuan kelompok ini ialah untuk memperoleh kekuasaan politik dan melalui kekuasaan itu, melaksanakan kebijakankebijakan mereka (Budiardjo, 2008:404). Dalam bukunya Ekonomic Et Societie Marx Weber memberikan defenisi tentang partai politik, menurutnya partai politik adalah organisasi publik yang bertujuan untuk membawa pemimpinnya berkuasa dan memungkinkan parapendukungnya (politisi) untuk mendapatkan keuntungan dari dukungantersebut (Firmanzah, 2008:66). Hasil penelitian yang dilakukan oleh Wance (2019) bahwa kemenangan sangat ditentukan oleh empat modal yaitu modal politik yang dimiliki kandidat selama membangun karier politik yang bernjenjang, kedua yaitu modal ekonomi sangat menentukan kandidat untuk membangun basis kekuatan di masyarakat, ketiga, modal budaya yaitu modal dalam bentuk kharisma yang lahir dari masyarakat sejak lahir dan mempunyai hubungan dengan masyarakat budaya. (Wance, 2019).

Menurut Ichlasul amal (1996:2), modul atau tipologi partai politik berdasarkan tingkat komitmen partai terhadap ideologi dan kepentingan terdapat lima jenis partai politik yaitu :

1. Partai proto adalah tipe awal partai politik sebelum mencapai tingkat perkembangan seperti dewasa ini. Ciri yang paling menonjol dari partai ini adalah pembedaan antara kelompok anggota atau "ins" dengan non anggota atau "outs" selebihnya partai ini belum menunjukkan ciri sebagai partai politik dalam pengertian modern. Karena itu sesungguhnya partai ini dibentuk berdasarkan pengelompokan ideologi masyarakat.

2. Partai kader merupakan perkembangan lebih lanjut dari partai proto. Keanggotaan partai ini terutama berasal dari golongan kelas menengah keatas. Akibatnya, ideologi yang dianut partai ini adalah konservatisme exstrim. Karena itu partai kader tidak memerlukan organisasi besar yang dapat memobilosasi massa.

3. Partai massa, muncul saat terjadi perluasaan hak pilih rakyat sehingga dianggap sebagai respon politis dan organisasional bagi perluasan hak-hak pilih serta mendorongbagi perluasan lebih lanjut hak-hak pilih tersebut. Partai massa berorientasi pada basis pendukungnya yang luas, misalnya buruh, petani, kelompok agama dan memiliki idiologi yang cukup jelas untuk memobilisasi massa serta mengembangkan organisasi yang cukup rapi untuk mencapai tujuantujuan ideologinya. 
(1) NAKHODA:

JURNAL

ILMU PEMERINTAHAN
NAKHODA: JURNAL ILMU PEMERINTAHAN

Edisi Januari - Juni Tahun 2020 Volume: 19 Nomor: 1

ISSN : 1829-5827 | E-ISSN : 2656-5277

DOI : https://doi.org/10.35967/jipn

https://nakhoda.ejournal.unri.ac.id/index.php/JIPN
4. Partai diktatorial sebenarnya merupakan sub-tipe dari partai massa, tetapi memiliki idiologi yang lebih kaku dan radikal. Pemimpin tertinggi partai melakukan kontrol yang sangat ketat terhadap pengurus bawahan maupun anggota partai. Rekrutmen anggota partai dilakukan secara lebih selektif dari pada partai massa.

5. Partai Catch-all merupakan gabungan dari partai kader dan partai massa. Istilah Catch-all pertama kali ditemukan oleh Otto Kirchheimer untuk memberikan tipologi pada kecenderungan perubahan karekteristik. Catch-all dapat diartikan sebagai "menampung kelompok-kelompok sosial sebanyak mungkin untuk dijadikan anggotanya." Tujuan utama partai ini adalah memenangkan pemilihan umum dengan cara menawarkan programprogram dan keuntungan bagi anggotanya sebagai pengganti idiologi yang kaku.

\section{METODE PENELITIAN}

Jenis penelitian yang digunakan dalam penulisan ini adalah jenis penelitian deskriptif kualitatif yaitu penelitian yang berusaha menggambarkan atau melukiskan obyek yang diteliti berdasarkan fakta yang ada di lapangan. Menurut Sugiyono (2007:1) Penelitian Kualitatif adalah metode yang digunakan untuk meneliti pada kondisi objek yang alamiah, dimana peneliti adalah instrumen kunci dan hasil penelitian lebih menekankan makna dari pada generalisasi.

Adapun Fokus penelitian ini merupakan batasan-batasan kajian dari variable yang diangkat dalam penelitian ini agar tidak meluas dan terjadi bias. Adapun fokus dalam penelitian ini antara lain sebagai berikut : (1) Sistem Kaderisasi. (2) Proses dan Penetapan Calon Anggota Legislatif.

Pertimbangan penetapan calon anggota legislatif kader dan non kader. Sumber data yang diperoleh dari data primer yaitu melakukan wawancara secara mendalam dengan informan yang dipilih dari pimpinan partai Nasdem serta data sekunder diperoleh dari literatur, dokumen partai dan observasi lapangan secara langsung.

\section{HASIL DAN PEMBAHASAN}

\section{Sistem Kaderisasi yang dilakukan oleh partai NasDem di Kabupaten Seram Bagain Barat}

Keyakinan akan arti penting kader bagi kelangsungan organisasi menjadikan pendidikan dan pengembangan kader sebagai salah satu fungsi Partai Nasdem. Dengan demikian, dapat dikatakan bahwa tugas pembinaan kader adalah salah satu tugas eksistensial partai Nasdem. Artinya, kegiatan pengkaderan adalah kegiatan yang hakiki yang berlangsung secara terencana dan berkesinambungan. Sistem Kaderisasi adalah bagian dari serangkain kegiatan penyiapan sumber daya manusia secara terdidik atau secara berkesinambungan agar kelak menghasilkan para pemimpin yang mampu membangun peran dan fungsi 
organisasi secara lebih bagus dalam jabatan-jabatan administratif maupun politik sekaligus mencari kader militan (sungguh-sungguh) yang dipersiapkan untuk mengganti pemimpin yang lamaSeperti penjelasan Yosias Apitula yang menjabat sebagai Sekretaris DPD Partai NasDem Kabupaten Seram Bagian Barat mengata. kan bahwa :

Proses kaderisasi di Partai NasDem berawal dari keinginan seseorang untuk bergabung bersama partai NasDem, Keinginan saja belum cukup seseorang tersebut dikatakan kader NasDem karena harus melalui yang namanya pelatihan/diklat kader untuk masuk didalam kepengurusan partai, yang mana didalam pelatihan tersebut mempunyai hirarki/jenjang pelatihan dari tingkat bawah (desa) sampai ketingkat Nasional ( wawancara, 31 Oktober 2019).

Salah satu bentuk dari pengembangan SDM dapat dilakukan melalui pendidikan dan pelatihan. justifikasi bahwa pendidikan dan pelatihan dapat meningkatkan kemampuan, keterampilan dan keahlian kader. Kader yang mengikuti pendidikan dan pelatihan akan mendapatkan pengetahuan, keterampilan, keahlian dan kecakapan sesuai bidang kerjanya. Dengan memiliki spesialisasi pekerjaan akan lebih memudahkan di dalam menyelesaikan pekerjaan, karena itu pendidikan dan pelatihan bagi kader penting dilakukan agar dapat menunjang kemampuan kader dalam mengoptimalisasikan kemampuan di dalam masyarakat. Kemampuan keterampilan dan keahlian tersebut akan memudahkan kader untuk mencapai hasil yang diinginkan oleh partai, secara kuantitas maupun kualitas akan lebih baik. Dalam pelaksanaannya pelatihan yang diselenggarakan oleh partai Nasdem, dalam mengoptimalisasikan kemampuan para kader. Maka kader harus mengikuti beberapa tahapan kaderisasi di partai Nasdem, adapun beberapa tahapan tersebut adalah sebagai berikut:

1) Tingkat desa, yang mana didalam pelatihan ini bertujuan untuk membentuk kader yang memahami betul orginisasi partai Nasdem, serta isu yang terbaru mengenai bentuk dan kondisi desa.

2) Tingkat kecamatan, yang mana didalam pelatihan ini bertujuan untuk membentuk kader yang memahami betul bentuk dan kondisi kecamatan.

3) Tingkat Kabupaten, yang mana didalam pelatihan ini bertujuanuntuk membentuk kader yang memahami betul bentuk dan kondisi dari wilayah kabupaten tersebut.

4) Tingkat nasional, yang mana didalam pelatihan ini bertujuan untuk membentuk kader yang memahami betul bentuk dan kondisi serta kebutuhan nasional.

Partai NasDem sesuai dengan petunjuk dan pedoman rencana induk kaderisasi yang menjadi panduan partai dalam melakukan kaderisasi. Yosias Apitula mencoba menjelaskan bahwa kaderisasi yang diberikan kepada kader itu 


\author{
NAKHODA: JURNAL ILMU PEMERINTAHAN \\ Edisi Januari - Juni Tahun 2020 Volume: 19 Nomor: 1 \\ ISSN : 1829-5827 | E-ISSN : 2656-5277 \\ DOI : https://doi.org/10.35967/jipn \\ https://nakhoda.ejournal.unri.ac.id/index.php/JIPN
}

penting, dikarenakan pelatihan yang diberikan oleh partai akan memberikan masukan kepada setiap kader dalam menyelesaikan masalah dan dinamika yang ada. Pada kesempatan lain, penulis akan menguraikan bagaimana cara partai dalam mengkader para calon kader, adapun hasil wawancara penulis dengan Yosias Apitula yang menjabat sebagai Sekretaris DPD Partai NasDem Kabupaten Seram Bagian Barat Kabupaten Seram Bagian Barat menyatakan bahwa: Seorang kader harus mengikuti bentuk pelatihan sebagai salah satu syarat menjadi pengurus partai, selain itu pelatihan yang diselenggarakan oleh partai untuk meningkatkan kemampuan para kader( Wawancara, 31 Oktobar 2019).

\section{1) Menjalani Proses Rekruitmen/seleksi calon anggota legislatif.}

Proses rekruitmen calon legislatif dari kader berdasarkan penilaian yang dilakukan oleh tim seleksi. Penilaian yang dilakukan oleh tim seleksi mencakup kecakapan yaitu kemampuan untuk menguasai suatu pengetahuan atau keterampilan tertentu, keuletan yaitu mampu memperjuangkan sesuatu secara tekun, tahan terhadap tekanan dan hambatan, prakarsa yaitu kemampuan dalam mengambil keputusan, militansi yaitu kemauan dan kemampuan berjuang keras dalam menghadapi kesulitan serta disiplin yaitu kemauan dan kemampuan untuk mentaati peraturan. Hal ini dikembangkan dan dinilai agar memenuhi syarat sebagai calon legislatif partai yang memiliki kemampuan yang kompeten.

Hal ini disampaikan oleh Mario Olswesky selaku wakil Ketua bidang
Politik dan Pemerintahan Partai NasDem bahwa :

Sumber rekruitmen bakal calon anggota legislatif partai NasDem antara lain sebagai anggota kepengurusan partai, anggota fraksi partai, anggota organisasi kemasyarakatan, organisasi sayap partai, anggota pengurus badan atau lembaga yang dibentuk oleh partai atau tokoh masyarakat yang memiliki kompetensi dan popularitas. 6 pokok sumber rekruitmen ini sebagai landasan bahwa NasDem mengutamakan kader-kadernya yang mampu dan berpotensi lalu mencari calon lain diluar kader partai. (wawancara 6 November 2019)

Proses rekruitmen yang dilakukan oleh partai politik NasDem lebih mengutamakan kader partai politiknya terlebih dahulu, hal ini berhubungan dengan pembekalan ilmu yanng telah diberikan kader-kadernya. Tetapi ini juga membuka peluang terhadap orang diluar kader untuk dapat mengajukan dirti sebagai calon anggota legislatif.

\section{2) Pendidikan dan Pelatihan Politik}

Maksud dan tujuan dari pendidikan dan pelatihan politik untuk kader adalah meningkatkan wawasan dan penghayatan peserta diklat tentang sejarah, idiologi, doktrin, paradigma baru dan kebijakan umum partai NasDem, hal ini juga berhubungan dengan meingkatkan motivasi, militansi, dedikasi dan kerjasama kelompok peserta agar dapat berperan secara optimal dalam melakukan tugastugas dari partai. Dalam meningkatkan 
kemampuan kader dalam berkomunikasi dengan masyarakat menentukan citra partai dimasa yang akan datang. Kaderpun wajib meningkatkan kemampuan meminta dukungan khususnya kalangan generasi muda. Hal ini lebih jelasnya diutarakan oleh Arifin Pondlan Grisya, SH selaku Ketua DPD Partai NasDem yaitu :

Materi-materi pembekalan pendidikan yang diberikan kepada kader-kader muda, mendukung akan kemampuan mereka dalam berpartai, mereka akan diberikan pembekalan ideology pancasila dalam kehidupan berbangsa dan bernegara, visi misi partai, keterampilan-keterampilan,

kepeloporan dan pengetahuan umum. Materi-materi yang diberikan selama ini terus menerus akan diperbaharui sesuai dengan perkembangan partai politik. Penguasaan materi pada saat pendidikan dan pelatihan politik merupakan penambahan penilaian untuk kader-kader muda pada saat diajukannya nama sebagai anggota calon legislatif. ( Wawancara 6 November 2019)

Dari pendapat nara sumber di atas dapat disimpulkan bahwa Pendidikan dan Pelatihan Politik yang diberikan oleh partai untuk kader dan anggota calon legislatif adalah pengalaman pendidikkan seorang kader meliputi pendidikan formal, non formal dan pendidikan kepartaian. Hasil dari pendidikan dan pelatihan ini akan sangat berguna pada saat kader atau anggota calon legislatif bertemu dengan masyarakat dan mengutarakan ide, pikiran visi dan misi partai.

\section{3) Proses Penetapan Daftar Calon Legislatif Sementara (DCS) \\ Partai NasDem dalam rangka} melakukan rekrutmen Calon Anggota DPRD kabupaten/kota menetapkan kualifikasi kader. Selain itu setiap bakal calon anggota legislatif harus melengkapi syarat-syarat umum dan administrative, sesuai dengan pasal 51 Undang-undang Nomor 8 tahun 2012 tentang pemilihan umum anggota dewan perwakilan rakyat, dewan perwakilan daerah, dewan perwakilan rakyat daerah, bakal calon anggota DPR-RI, DPRD Provinsi, dan DPRD Kabupaten/Kota.

Sedangkan wewenang dalam penetapkan calon anggota DPRD Kabupaten/Kota adalah sebagai berikut:

a) Wewenang untuk melakukan proses seleksi dan penetapan calon anggota DPRD Kabupaten/Kota berada pada DPD partai NasDem Kabupaten/Kota yang dilaksanakan oleh tim seleksi dan penetapan calon anggota DPRD Kabupaten/Kota.

b) Tim seleksi dan penetapan calon anggota DPRD Kabupaten/Kota dipimpin oleh ketua DPD Kabupaten/Kota dengan anggota : sekretaris, bendahara, wakil ketua bidang Oranisasi, keanggotaan dan Kaderisasi, wakil ketua Pemilihan Umum, wakil ketua Bidang Kesehatan, Perempuan dan Anak, wakil ketua bidang Politik dan Pemerintahan, wakil ketua bidang Olahraga, Pemuda dan Mahasiswa.

c) Dalam menetapkan daftar calon anggota DPRD Kabupaten/Kota (DCS-DCT), DPD partai NasDem Kabupaten/Kota wajib 


\author{
NAKHODA: JURNAL ILMU PEMERINTAHAN \\ Edisi Januari - Juni Tahun 2020 Volume: 19 Nomor: 1 \\ ISSN : 1829-5827 | E-ISSN : 2656-5277 \\ DOI : https://doi.org/10.35967/jipn \\ https://nakhoda.ejournal.unri.ac.id/index.php/JIPN
}

memperhatikan pertimbangan dari ketua pimpinan kecamatan partai NasDem terkait, berdasarkan hasil evaluasi kinerja kader bersangkutan sebagai fungsionaris partai NasDem.

d) Dewan pertimbangan DPD partai NasDem Kabupaten/Kota dapat memberikan pertimbangan terhadap daftar calon sementara yang telah disusun oleh tim seleksi dan penetapan calon anggota DPRD Kabupaten/Kota.

e) Sebelum DPD partai NasDem Kabupaten/Kota menetapkan daftar calon (DCS-DCT) diharuskan berkonsultasi dengan DPD partai NasDem Provinsi untuk memperoleh persetujuan.

f) Penetapan (DCS-DCT) anggota DPRD Kabupaten/Kota dilakukan oleh tim seleksi dan dilaporkan dalam rapat Pleno DPD partai NasDem Kabupaten/Kota.

Sebagaimana penemuan dan hasil penelitian penulis, partai NasDem sesuai dengan Pedoman Penyusunan Daftar Calon Anggota DPR-RI, DPRD Provinsi, Dan Dprd Kabupaten/Kota Partai NasDem yang menjadi panduan partai dalam penyusunan daftar caleg di Kabupaten Seram Bagian Barat. Dari hasil wawancara dengan Arifin Pondlan Grisya, SH selaku Ketua DPD Partai NasDem, mengenai bagaimana proses penetapan calon anggota legislatif di partai NasDem Yosias Apitula mengatakan bahwa:

Dibentuknya tim seleksi yang mempunyai wewenang dalam menyeleksi kembali kader-kader yang akan diikutsertakan dalam pencalonan anggota legislatif pada pemilu di kabupaten Seram Bagian Barat. (Wawancara 6 November 2019).

Senada dengan apa yang disampaikan Arifin Pondlan Grisya, SH, Yosias Apitula selaku Sekretaris DPD Partai NasDem, mengatakan bahwa:

Tim seleksi yang hanya dihadiri oleh orang-orang tertentu yang mempunyai tanggung jawab dalam menjaring kembali kader-kader yang berkeinginan menjadi calon anggota dewan. (Wawancara 6 November 2019)

Dari beberapa pendapat narasumber di atas, Penetapan daftar calon legislatif adalah serangkaian kegiatan partai dalam menetapkan calon anggota DPRD kabupaten/Kota, yang mana dalam proses penetapan tersebut partai akan membentuk tim yang mempunyai legalitas atau wewenang dalam penentuan kader yang akan menjadi daftar calon sementara dan daftar calon tetap (DCS-DCT) dari partai NasDem di Kabupaten Seram Bagian Barat. Partai NasDem sebagai partai yang belum lama berdiri juga memiliki pola rekruitmen politik, di mana rekruitmennya bertujuan sebagai kaderisasi anggota partai dengan tujuan mendapat suara dalam pemilu 2019, serta pelebaran jumlah anggota dengan mekanisme rekruitmen dapat dijadikan basis massa suara dalam menghadapi pemilu di tahun-tahun yang akan datang. Partai yang baik secara internal salah satunya dilihat dari mekanisme keanggotaan.

Tak hanya itu, proses rekruitmen juga merupakan fungsi mencari dan mengajak orang-orang yang memiliki kemampuan untuk turut aktif dalam 
kegiatan politik, yaitu dengan cara menempuh berbagai proses penjaringan, yang nantinya akan diusung sebagai calon legislatif. Implementasi rekruitmen politik mencakup rekruitmen anggota, rekruitmen pengurus, rekruitmen calon anggota legislatif, calon kepala daerah dan wakil kepala daerah. Adapun rekapitulasi Jumlah perolehan suara anggota dewan perwakilan rakyat daerah kabupaten Seram Bagian Barat dalam pemilu legislatif tahun 2019.

Tabel 1

Rekapitulasi Jumlah Perolehan Suara Dalam Pemilu Legislatif tahun 2019

\begin{tabular}{|l|l|l|l|l|l|l|l|}
\hline No & $\begin{array}{c}\text { Nama } \\
\text { Partai }\end{array}$ & $\begin{array}{c}\text { Dapil } \\
1\end{array}$ & $\begin{array}{c}\text { Dapil } \\
2\end{array}$ & $\begin{array}{c}\text { Dapil } \\
3\end{array}$ & $\begin{array}{c}\text { Dapil } \\
4\end{array}$ & $\begin{array}{c}\text { Dapil } \\
5\end{array}$ & $\begin{array}{c}\text { Total } \\
\text { Suara }\end{array}$ \\
\hline 1 & NasDem & 2.889 & 3.608 & 2.342 & 2.871 & 2.041 & 13.751 \\
\hline
\end{tabular}

Sumber: KPU Kabupaten Seram Bagian Barat

Berdasarkan data rekapitulasi tahun 2019 partai NasDem memperoleh empat orang yang terpilih menjadi anggota legislatif di Kabupaten Seram
Bagian Barat,. Adapun nama-nama kader dari partai NasDem yang duduk menjadi anggota legislatif pada tahun 2019.

Tabel 2

Perolehan Kursi Partai NasDem Dalam Pemilihan Umum Anggota Legislatif Daerah Kabupaten Seram Bagian Barat tahun 2019

\begin{tabular}{|c|c|c|c|}
\hline No & Nama & Dapil & Suara \\
\hline 1 & Arifin Pondlan Grisya, SH & 1 & 1.053 \\
\hline 2 & Hamza Wakano, SH, MH & 2 & 1.651 \\
\hline 3 & Sumardi & 3 & 692 \\
\hline 4 & Muhammad Djosen Kaisupy, ST & 4 & 1.228 \\
\hline
\end{tabular}

Sumber: KPU Kabupaten Seram Bagian Barat

Dari tabel di atas dapat dilihat bahwa partai NasDem sebagai salah satu partai pemenang peserta pemilu yang mendapatkan suara terbanyak kedua setelah partai Hanura, Partai NasDem juga mampu memposisikan kadernya di lembaga legislatif di kabupaten Seram Bagian Barat.

Dapat disimpulkan bahwa partai NasDem memberikan pembekalan terhadap para kader dan kepada calon anggota legislatif agar lebih mengutamakan kualitas dalam mengemban tugas-tugas partai. Hasil penelitian ini menunjukkan bahwa sistem kaderisasi Partai NasDem Kabupaten Seram Bagian Barat menggunakan sistem Stelsel Aktif (masyarakat aktif) dan Bottom Up (usulan dari bawah) dengan metode yang digunakan adalah diskusi dan penyajian materi. Implementasinya 
adalah melalui Kader Penggerak Cepat (KPC) sebagai tim rekrutmen kader. Setelah diadakan rekrutmen kader, Kader ini dicetak untuk meneruskan perjuangan organisasi dengan tetap mengacu pada program kerja dan Anggaran Dasar dan Anggaran Rumah Tangga Partai NasDem.

\section{Pertimbangan Partai Dalam Menetapkan Calon Anggota Legislatif}

a) Memenuhi ketentuan yang disyaratkan oleh undangundang.

Ketentuan yang disyaratkan oleh undang-undang untuk menjadi calon anggota legislative antara lain : melalui tahapan pencalonan, telah aktif sebagai kader atau ormas yang didirikan oleh partai, tidak pernah dijatuhi hukuman pidana penjara yang diatas 5 tahun atau lebih, didukung 30\% dari pemegang hak suara, pendidikan minimal SMA/ sederajat, aktif sebagai anggota partai minimal 5 tahun, pernah mengikuti pendidikan dan pelatihan kader, memilki prestasi dedikasi disiplin loyalitas dan tidak tercela, tidak pernah terlibat G-30 S/PKI dan bersedia meluangkan waktu dan sanggup bekerjasama secara kolektif dalam partai.

Dari hasil penelitian penulis, sebagaimana dengan hasil wawancara dengan Yosias Apitula Selaku Sekretaris DPD Partai NasDem, mengatakan bahwa:

Setiap calon yang akan diusung harus memiliki 4 kriteria yang sesuai dengan petunjuk/ pedoman dari pusat, selain itu kader yang dicalonkan harus mempunyai elektabilitas yang tinggi terhadap keterpilihan kader di masyarakat" (Wawancara 6 November 2019).

Partai NasDem dalam menetapkan calon yang akan diusung dalam pemilu legislatif sesuai dengan petunjuk dan pedoman dari pusat, kader yang diharapkan dapat menjaga mobilitas organisasi partai dan mampu menyerap aspirasi masyarakat untuk dirumuskan menjadi kebijakan partai yang harus diperjuangkan.

\section{b) Pertimbangan partai yang non} kader

Memasuki pemilu 2019, sistem pemilu berubah menjadi sistem proposional daftar terbuka. Sistem ini telah mendorong terjadinya perubahan strategi partai dalam memenangkan pemilu. Partai tidak lagi dominan baik dalam penentuan caleg, maupun dalam pemenangan pemilu. Sistem kompetisi terbuka antar calon legsilatif di dalam internal partai mendorong gairah calon legislatif untuk berjuang dengan segala cara agar dapat menperoleh suara tertinggi di dalam partai supaya lolos menjadi anggota legislatif.

Beberapa pertimbangan mengapa seseorang dapat direkrut, walaupun bukan kader partai, yaitu: pertama Karena modal sosial dan kedua mempunyai modal ekonomi. Modal sosial terkait dengan banyaknya pengikut yang seseorang miliki karena posisinya baik sebagai tokoh agama, tokoh politik, maupun tokoh masyarakat lainnya. Modal ekonomi terkai dengan kekayaan yang dia miliki, biasanya mereka adalah seorang pengusaha atau 
orang yang mempunyai kekayaan cukup untuk mendanai kampanye pemenangan pemilu.

Dari hasil penelitian penulis, tidak ada pedoman pencalonan legislatif di partai NasDem dalam merekrut calon anggota legislatif yang bukan dari kader partai, tetapi penulis mendapatkan informasi dari beberapa hasil wawancara bahwa calon yang non kader haruslah menjadi kader partai terlebih dahulu dengan dibuktikannya Kartu Tanda Anggota, setelah itu barulah partai dapat mencalonkan kader tersebut menjadi colon legislatif yang diusung oleh partai, sesuai dengan mekanisme penetapan yang dilakukan oleh partai NasDem.

Adapun data yang penulis dapat dari hasil wawancara di partai NasDem adalah sebagai berikut:

a. Ketokohannnya, yang dimaksud disini adalah calon tersebut mempunyai figur yang baik dimata masyarakat dan mampu bersaing dengan kandidatkandidat lain.

b. Finansial, yang dimaksud disini adalah calon tersebut mempunyai modal yang cukup untuk melakukan kampanye.

c. Intelektual, yangdimaksud disini adalah seseorang yang mempunyai kemampuan yang baik dalam menyelesaikan masalah-masalah yang terjadi dimasyarakat.

d. Massa, yang dimaksud disini adalah seseorang mempunyai pengaruh atau pendukung yang relatif besar dimasyarakat.

Memenuhi ketentuan yang disyaratkan oleh undang-undang, yang dimaksud disini adalah bahwa orang yang akan dicalonkan tidak tersangkut pidana, mampu bertanggung jawab dan lain-Lain. Partai NasDem memiliki kebijakan untuk memilih atau menetapkan calon anggota legislative yang bukan dari kader partai, hal ini di utarakan dan di ungkapkan oleh Mario Olswesky selaku wakil Ketua bidang Politik dan Pemerintahan Partai NasDem sebagai berikut :

Kebijakan partai sejak tahun 2013 mengatakan bahwa partai NasDem dapat menetapkan atau mencalonkan anggota legislatif diluar kader, hal ini menyangkut akan kemampuan, kompetensi dan dasar hokum yang jelas bahwa calon anggota legislatif tersebut mampu membawa visi misi partai kearah yang lebih baik untuk kepentingan masyarakat. (Wawancara 8 November 2019).

Kebijakan partai dalam menetapkan dan memilih calon anggota legislative diluar kader partai dilakukan untuk mendongkrak popularitas partai dengan memilih orang-orang yang berkompeten dan berprestasi di masyarakat. Dengan demikian pada pemilu legislatif 2019 sedikit banyak telah menegaskan pendekatan idiologis. Para kader partai bisa pindah ke partai manapun yang dia suka dan bisa menerimanya menjadi caleg, tanpa hirau dengan identitas idiologis dan historis. Begitupun partai bisa menerima setiap orang yang akan menjadi caleg dari partai yang bersangkutan yang dianggap mempunyai potensi, baik ekonomi maupun politik. 
3. Strategi partai dalam menjaga kader agar tidak pindah ke partai lain

a. Memberikan jabatan-jabatan strategis

Partai NasDem memberikan jabatanjabatan kepada kader-kader yang memiliki potensi dan kemampuan. Seperti halnya jabatan sebagai fungsionaris partai dengan pengalaman dan memberikan rencana kerja yang spesifik, kader dapat dinilai sukses dan berprestasi sehingga mampu membawa visi misi partai dimasa yang akan datang. Hal ini disampaikan oleh Yosias Apitula selaku Sekretaris DPD Partai NasDem bahwa :

Partai pasti akan menempatkan orang-orang yang berkompeten di posisi-posisi dengan jabatan partai yang bagus. Hal ini ditunjang dari kemampuan, keuletan dan prestasi dari kader untuk menunjukan bahwa kader mampu menyelesaikan tugas yang telah diberikan oleh partai. Setiap kader yang dianggap mampu dan berprestasi pasti masuk dalam penilaian sehingga dapat ditempatkan ditempat yang cocok dengan kemampuannya. (Wawancara 6 November 2019)

Berdasarkan analisa penulis sesuai yang didapat dalam wawancara bahwa strategi partai dalam menjaga kaderkadernya agar tidak berpindah ke partai lain antara lain adalah memberi penghargaan dan jabatan kepada kader yang berprestasi. Penghargaan dan jabatan yang diberikan oleh kader yang berprestasi secara continue dilakukan untuk regenerasi anggota fungsionaris partai NasDem.

\section{b. Memberikan Insentif ( Gaji )}

Cara lain agar kader tidak berpindah kelain partai adalah dengan memberi insentif atau gaji kepada kader. Biasanya hal ini sebagai motivasi kepada kader yang memberikan waktu, tenaga dan fikirannya untuk memajukan partai.

Hal ini disampaikan oleh Yosias Apitula selaku Sekretaris DPD Partai NasDem yang mengatakan bahwa : Tidak ada strategi khusus partai NasDem dalam menjaga kader-kadernya, biasanya selain memberikan Insentif gaji, partai dalam menjaga kader juga turun ke tingkat pengurus didesa dalam menjaga silaturahmi dan mengajak kader-kader di tingkat desa untuk terlibat dalam kegiatan partai (Wawancara 6 November 2019)

Partai dalam menjaga kadernya agar tidak pindah ke partai lain dalah dengan memberikan Jabatan Strategis, insentif dan melakukan Silaturrahmi ke pengurus Desa. Adapun data yang coba di kumpulkan penulis mengenai strategi partai dalam menjaga kadernya adalah dengan Notulen Reses, Notulen Reses adalah tanggung jawab serta kewajiban bagi kader partai yang duduk menjadi dewan perwakilan rakyat yang mana setiap setahun sekali para anggota dewan tersebut turun kemasyarakat dalam menampung aspirasi masyarakat.

\section{KESIMPULAN}

1. Sistem kaderisasi yang dilakukan oleh partai Nasdem di Kabupaten Seram Bagian Barat. Sistem kaderisasi partai Nasdem antar lain adalah memberikan pelatihan bagi kader sebagai salah satu bentuk pengembangan sumber daya 


\author{
NAKHODA: JURNAL ILMU PEMERINTAHAN \\ Edisi Januari - Juni Tahun 2020 Volume: 19 Nomor: 1 \\ ISSN : 1829-5827 | E-ISSN : 2656-5277 \\ DOI : https://doi.org/10.35967/jipn \\ https://nakhoda.ejournal.unri.ac.id/index.php/JIPN
}

manusia. Didukung nilai manfaat yang dapat diambil dari pendidikan dan pelatihan yaitu dapat menunjang kelancaran tugas partai. Karena kader yang pernah mengikuti pelatihan akan memiliki kemampuan, keterampilan, dan keahlian serta kecakapan untuk menjalankan tugas- Tugas serta tanggung jawab yang diberikan partai politik sebagai salah satu kualifikasi yang dimiliki seorang kader. Dalam perspektif partai, kompetensi dalam menjalankan tugas serta tanggung jawab untuk mengaktualisasikan kebijakan untuk mengemban misi partai menuju pencapaian tujuan dan cita-cita yang harus dimiliki kader partai Nasdem.

2. Proses penetapan calon anggota legislatif yang dilakukan oleh partai Nasdem di Kabupaten Seram Bagian Barat. yaitu menjalani Proses Rekruitmen/seleksi calon anggota legislatif. Proses rekruitmen calon legislatif dari kader berdasarkan penilaian yang dilakukan oleh tim seleksi. Penilaian yang dilakukan oleh tim seleksi mencakup kecakapan yaitu kemampuan untuk menguasai suatu pengetahuan atau keterampilan tertentu, keuletan yaitu mampu memperjuangkan sesuatu secara tekun, tahan terhadap tekanan dan hambatan, prakarsa yaitu kemampuan dalam mengambil keputusan, militansi yaitu kemauan dan kemampuan berjuang keras dalam menghadapi kesulitan serta disiplin yaitu kemauan dan kemampuan untuk mentaati peraturan. Serta dalam meningkatkan kemampuan kader dalam berkomunikasi dengan masyarakat menentukan citra partai dimasa yang akan datang. Kader pun wajib meningkatkan kemampuan meminta dukungan khususnya kalangan generasi muda. Selain itu calon kader wajib memiliki kompetensi yang memadai untuk menjalankan tugastugas sebagai anggota legislatif, memiliki pengabdian dan rekam jejak yang baik selama aktif dipartai Nasdem, memiliki prestasi, dedikasi, disiplin, loyalitas dan tidak tercela (PD2LT), dan memenuhi ketentuan yang disyaratkan oleh undang-undang.

3. Pertimbangan Partai NasDem dalam menetapkan calon anggota legislatif yang bukan dari kader Partai NasDem. Pertama karena modal sosial dan kedua mempunyai modal ekonomi. Modal sosial terkait dengan banyaknya pengikut yang seseorang miliki karena posisinya baik sebagai tokoh agama, tokoh politik, maupun tokoh masyarakat lainnya. Modal ekonomi terkait dengan kekayaan yang dia miliki, biasanya mereka adalah seorang pengusaha atau orang yang mempunyai kekayaan cukup untuk mendanai kampanye pemenangan pemilu.

\section{DAFTAR PUSTAKA}

Andrianus Pito, Toni, dkk. Mengenal Teori-teori Politik, Nuansa, Bandung,

2006.Suprihatini, Amin. Partai Politik Di Indonesia, Cempaka Putih, Klaten, 2008.

Budiarjo, Miriam. Dasar-dasar Ilmu Politik, PT.Gramedia Pustaka Utama, Jakarta, 2006. 
Harahap, Abdul Asri, 2005. Manajemen dan Resolusi Konflik Pilkada, PT.Pustaka Cidesindo, Jakarta.

Amal, Ichlasul, 1996. Teori-teori Mutakhir Partai Politik. PT. Tiara Wacana Yogya. Yogyakarta.

King, Dwight Y., Pemilihan Umum 1955 dan 1999 Keserupaan dan Kesinambungan, Makmur Makka (Eds), Jakarta, 2002.

Moleong, Lexy J, 2004. Metodologi Penelitian Kualitatif. Remaja Rosda Karya, Bandung.

Rahman H.I, A, 2007. Sistem Politik Indonesia. Graha Ilmu, Yogyakarta.

Rudy, T.May, Pengantar Ilmu Politik, PT.Refika Aditama, Bandung, 2003.

Soemantri. Sistem-sitem Pemerintahan Negara,Bandung. 1976

S.Padmuji, Teori Sistem dan Penerapannya dalam Manajemen, Jakarta, Bima Aksara. 1985

Sugiyono, 2007. Memahami Penelitian Kualitatif. Alfabeta, Bandung.

Syafii, inu kencana dan Azhari. 2002. Sistem Politik Indonesia. Cetakan Kelima. PT Refika Aditama. Bandung.

Wance, M., \& Djae, R. M. (2019). MODALITAS DINASTI AHMAD

$\begin{array}{lrr}\text { HIDAYAT } & \text { MUS } & \text { PADA } \\ \text { PEMILIHAN } & \text { KEPALA } & \text { DAERAH } \\ \text { DI } & \text { MALUKU } & \text { UTARA }\end{array}$

2018. Sosiohumaniora, 21(3), 256268.

DOI

: https://doi.org/10.24198/sosiohuma niora.v21i3.21547

Wance, M., \& La Suhu, B. (2019). Partisipasi Pemilih Pemula Dalam Menentukan Pilihan Politik Pada Pemilihan Kepala Daerah Maluku Utara. JOURNAL $O F$ GOVERNMENT (Kajian Manajemen Pemerintahan dan Otonomi Daerah), 4(2), 91-115.

\section{Dokumen-dokumen}

Undang-Undang Nomor 2 tahun 2008 tentang Partai Politik.

Undang-undang No.2 Tahun 2011 tentang Partai Politik

Undang-Undang Partai Politik No. 2 tahun 2011 Pasal 29 Ayat (2) Bab XI tentang Rekrutmen Politik

Undang-undang Repiblik Indonesia Nomor 3 Tahun 1999 tentang pemilihan umum

Undang-Undang Pemilu Nomor 15 Tahun 2011 tentang Penyelenggaraan Pemilu 